\title{
Plasma Protein Determination as a Clinical Probe for Liver Injury in Rats Induced by Thioacetamide, Alloxan or Ixoten
}

\author{
By F. M. Fouad, M. Goldberg and G. Ruhenstroth-Bauer \\ Max-Planck-Institut für Biochemie, Arbeitsgruppe Experimentelle Medizin, Martinsried, FRG
}

(Received April 19/August 26, 1982)

Summary: As a result of traumata, cancer or chemical poisoning the level of acute-phase proteins released by the liver undergoes a significant change which can be measured by two-dimensional immunoelectrophoresis. To investigate whether inflammatory reactions following chemical poisoning, tissue necrosis or other treatments result in an uniform change of the plasma protein profile, we examined quantitatively the change in plasma protein profile in the following model situations:

1) alloxan-induced diabetes in rats,

2) thioacetamide-induced liver cirrhosis and

3) ixoten-induced blocking of DNA synthesis in rat liver.

Even though the three agents used in the present study or their metabolites directly interacted with liver cells, they did not evoke a uniform change of the plasma protein profile.

Die Bestimmung der Plasmaproteine als klinische Untersuchungsmethode bei Leberschäden von Ratten nach Thioacetamid, Alloxan-bedingtem Diabetes und Ixoten

Zusammenfassung: Nach Traumata, bei Krebs oder bei Vergiftung zeigt das Profil der von der Leber produzierten „Akute-Phase-Proteine“ eine deutliche Veränderung, meßbar mit der zwei-dimensionalen Immunelektrophorese. Um festzustellen, ob eine Entzündung nach einer Vergiftung, Gewebsnekrose oder ähnlichem eine gleichförmige Veränderung des Plasmaprotein-Profils hervorruft, bestimmten wir quantitativ die Veränderung des Plasmaprotein-Profils der Ratte in den folgenden Modellen:

1. Alloxan-bedingter Diabetes,

2. Lebercirrhose, verursacht durch Thioacetamid und

3. Blockierung der Leberzell-DNA-Synthese durch das Zytostatikum Ixoten.

Wenn auch diese drei Substanzen oder deren Stoffwechselprodukte auf die Leberzellen einwirken, waren die Veränderungen des Plasmaprotein-Profils deutlich unterschiedlich.

\section{Introduction}

A group of plasma proteins known as acute-phase proteins undergo a dramatic change in their concentrations in response to trauma (1), cancer (2), chemical poisoning (3) etc. These changes may result in decreased concentrations of prealbumin, albumin and transferrin, and in increased amounts of $\alpha-1$ acid glycoprotein, haptoglobin, $\alpha$-1-antitrypsin, peak " $X$ " and in other rat serum proteins (3). Sever- al mechanisms have been described to account for these changes (1). The question that persists is: does inflammatory reaction following chemical intoxication, tissue necrosis or other treatment result in a uniform change of the plasma protein profile, in accordance with the use of the plasma protein profile as a probe for liver cell injury in clinical diagnosis. To investigate this possibility, we examined quantitatively the changes in the plasma protein profile, es- 
pecially acute-phase proteins, as determined by twodimensional immunoelectrophoresis, in the following model situations:

1) alloxan-induced diabetes in rats,

2) thioacetamide-induced liver cirrhosis in rat, and

3) blocking rat liver cell DNA synthesis by the cytostatic agent ixoten.

\section{Experimental}

\section{Animals}

Specific pathogen-free Wistar rats (Institut für Strahlen- und Umweltforschung. Neuherberg/München) weighing 150-170 g were used. Food (Altromin 1324) and water were given ad libitum. Room lighting was controlled on a $12 \mathrm{~h}$ dark: $12 \mathrm{~h}$ light regime. Animals were weighed before sacrifice.

\section{Chemicals and reagents}

Alloxan was purchased from Sigma/München (FRG), thioacetamide from Merck/Darmstadt (FRG). Ixoten was the generous donation of Asta/Bielefeld (FRG). Polyvalent rabbit antiserum against rat serum proteins was purchased from Boehringer/Mannheim (FRG).

\section{Two-dimensional immunoelectrophoresis}

Development of immunoprecipitates and quantitation of their areas were determined according to procedure developed in our laboratories (4). $6 \mu \mathrm{l}$ of rat serum were applied to agarose gel (Behringwerke/Marburg/L., FRG; $10 \mathrm{~g} / 1$ barbital buffer $\mathrm{pH}=8.6$ ) and separation of plasma proteins was carried out using the modified Desaga UGI apparatus (Desaga, Heidelberg, FRG). Polyvalent rabbit antiserum against rat serum proteins was used for the second immunoelectrophoretic run. Immunoprecipitates were characterized by differential staining methods (5), and other physicochemical parameters or biochemical functions (6). Quantitation of the immunoprecipitates was done using a digital planimeter (Digiplan AMO2; Kontron GmbH, München, FRG) after defined enlargement by projection. The percentage increase or decrease of identified serum proteins was estimated by comparing given peak areas within the electropherogram of the standard pool of control rat sera and the sera of experimental animals. Figure 1 is a typical example.

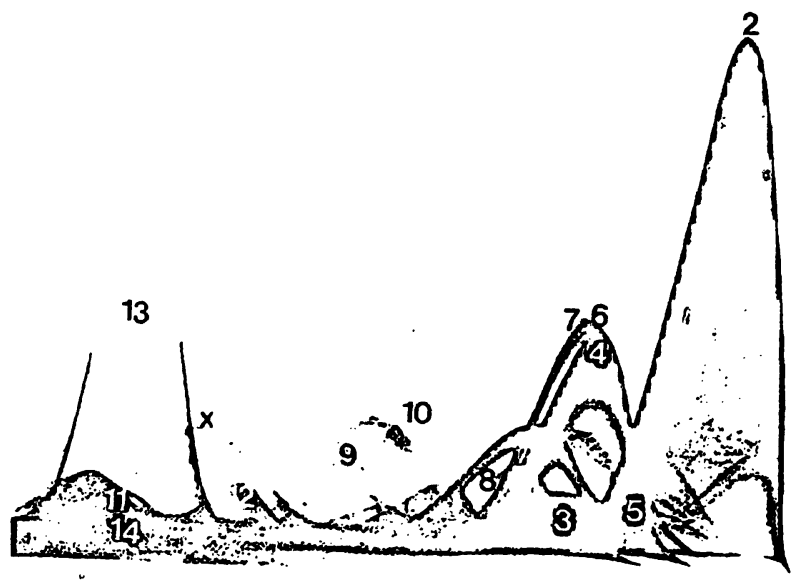

Fig. 1. Crossed two-dimensional immunuelectrophoresis of control rat serum. 1, Prealbumin; 2, albumin; 3, $\alpha$-lipoprotcin; 4, $\alpha$-1-macroglobulin; $5, \alpha-1$-acid glycoprotein; $6, \alpha-$ 1-antitrypsin; 7, cholinesterase; 8 , ceruloplasmin; 9 , haemopexin; 10 , haptoglobin; $11, \mathrm{C} 3 ; 12, \mathrm{C} 3 \mathrm{c} ; 13$, transferrin; $14, \beta$-lipoprotein; $X$, unidentified peak.

\section{Alloxan-induced diabetes model}

Diabetes was produced by an intrajugular injection of $0.2 \mathrm{ml}$ alloxan solution $(50 \mathrm{mg} / \mathrm{kg}$ body weight). At cach time interval (tab. 1), weights of rats to be sacrified were determined and blood of these rats was withdrawn and serum separated. Free glucose in serum was estimated according to Barthelmai \& Czok (7). Saline $(0.2 \mathrm{ml})$ was introduced intrajugularly into control rats.

In a separate set of experiments, 9 diabetic rats (14 days; with a mean free glucose value of $6.2 \pm 0.04 \mathrm{~g} / \mathrm{l}$ serum) were injected with carageenan $(0.2 \mathrm{ml}$ of $2 \mathrm{~g} /$ solution in saline in the hind paw). Blood $(0.2 \mathrm{ml})$ was collected from the animal (tail) prior to injection of carageenan to serve as a control. Similarly, over a period of three days, blood was collected and serum separated for immunoelectrophoresis (tab. 2).

\section{Thioacetamide-induced liver cirrhosis}

A solution of thioacetamide $(300 \mathrm{mg} / \mathrm{l})$ replaced drinking water. The experiment lasted 140 days. Blood was withdrawn from three rats at each time point (fig. 2) and serum was separated. Livers were removed at once for histology. Control animals were kept under the same conditions and were provided with fresh water.

In a separate set of experiments, rats with severe liver cirrhosis (140 days) were divided into two groups, 9 animals each, and were provided with fresh water for three days prior to partial hepatectomy. Partial hepatectomy according to Higgins \& Anderson (8) was carried out on one group. Partially hepatectomized rats and controls were provided with fresh water for another two weeks before blood was withdrawn for immunoelectrophoretic analysis, and liver was removed for histological examinations.

\section{Ixoten-poisoned model}

Ixoten solution ( $1 \mathrm{ml}$ of 50 or $100 \mathrm{mg}$ ixoten in saline per $\mathrm{kg}$ body weight) was injected i.p. in rats. At given time intervals, blood was withdrawn and serum was separated for immunoelectrophoretic analysis (tab. 3).

\section{Implantation of Yoshida-sarcoma tumour in rats}

Rats bearing Yoshida sarcoma (solid type) were generously donated by Prof. Dr. Gericke, Laboratorium für Krebsforschung (Hoechst AG, FRG). Yoshida sarcoma tumours were removed after about ten days when the tumour diameter reached about $5 \mathrm{~cm}$. The tumours were dissected in sterile $9 \mathrm{~g} / \mathrm{NaCl}$ solution to remove connective and necrotic tissue. Pieces of this tumour material (2-3 mm diameter) were implanted s.c. into experimental rats. Solid tumour reached $15-22 \%$ of body weight of the rat approximately 12 days after transplantation of the tumour.

The 12-days Yoshida sarcoma bearing rats were either injected i.p. with ixoten or the tumours were surgically removed followed by i.p. injection with ixoten.

\section{Histology}

At a given time interval, rats were sacrified and frozen sections $(8 \mu \mathrm{m})$ were prepared from the liver with a SLEE-Kryotom. After 80 and 140 days of thioacetamide administration the liver samples were fixed according to Davidson ( $96 \%$ ethanol: formalin: glacical acetic acid: water $=4+2+1+3$ by volume) and embedded in Paraplast. All histological preparations were stained according to Weigert/Eosin with ferric hematoxylin.

\section{Results and Discussion}

The diabetic model

Low concentrations of alloxan were used in our studies in order to increase the life span of the diabetic animals and to avoid the severe disaggregation of the 
normal membrane ribosome mRNA unit which may result when higher doses of alloxan are applied (9). Diabetic rats lost weight continually, whereas levels of free glucose in serum increased (tab. 1). Within the first 7 days, free glucose in serum reached $5.60 \mathrm{~g} / 1$ serum with a concomitant increase in levels of $\alpha$-1-acid glycoprotein (+164\%), $\alpha$-1-antitrypsin $(+121 \%)$, peak " $X$ " $(+42 \%)$ and haptoglobin $(+14 \%)$ and a decrease in albumin $(-35 \%)$, macroglobulin $(-50 \%), \mathrm{C} 3 \mathrm{c}+\mathrm{C} 3$ system $(-30 \%)$ and transferrin $(-23 \%)$ on the 7 th day. This rather typical acute-phase response may be due to two factors:

a) the inflammatory effects of alloxan on liver cells,

b) the injury due to the intrajugular introduction of alloxan.

This increase in glycoprotein levels during the first 7 days in diabetic rats with high free glucose in serum can be accounted for by considering the glycoprotein synthesis as a possible main pathway of glucose metabolism, which is not under the control of insulin. Except for $\alpha$-1-acid glycoprotein and albumin, the amounts of identified serum proteins decreased sharply on the tenth day of the experiment (tab. 1), which is indicative of an apparent decrease in the biosynthesis of excretable serum proteins by polyribosomes bound to the rough endoplasmic reticulum. It is known that in diabetic models, a reduction in bound ribosomes is generally, associated with a loss of rough endoplasmatic reticulum per volume cytoplasm $(9,10)$. Our observations agree with data reported by several authors, namely:

(a) Golgi and plasma membranes, which are known to control the termination of the heterosaccharide moities of the secretory plasma proteins and their accumulation and secretion, undergo morphological and biochemical variations in alloxan induced diabetes (11). (b) In cell-free system, mitochondria and microsomes, isolated from livers of alloxan diabetic rats, incorporated less radioactive amino acids into their protein in vitro compared with controls (12). This depressed incorporation of amino acids by the microsome system is primarily due to alterations in the ability of the microsomes to assemble amino acids into polypeptide chains; only a small part can be attributed to the failure of the soluble fraction of the liver to prepare amino acids for incorporation (12).

(c) In a closely related model, isolated perfused livers from streptozotocin-diabetic rats showed a decreased capacity to synthesise plasma proteins as compared with controls (13). However, the relative rates of synthesis of the seromucoid proteins, as a proportion of the rates of synthesis of albumin or total proteins, was approximately twice as great as in control livers (13).

Nevertheless, the decrease in the biosynthesis of excretable proteins by rough endoplasmatic reticulum bound polyribosomes may not necessarily be the sole factor behind the observed decrease in the levels of estimated serum proteins (tab. 1). It is documented that in diabetic and liver-damaged rats, the hepatic uptake mechanism of glycoproteins, mediated by receptors can be impaired both by modifications in the carbohydrate structure of glycoproteins and by functional changes in cell surface receptors (14). This results in changes in catabolism of some serum proteins which would influence their net concentration in the diabetic rat serum.

Diabetic rat livers responded to the extra inflammation caused by the injection of carageenan, by increased biosynthesis of the identified plasma proteins, except for albumin and macroglobulin, and by

Tab. 1. Relative concentration of plasma proteins of rats following the administration of alloxan ( $50 \mathrm{mg} / \mathrm{kg}$ body weight), in comparison to healthy controls. Values are the average of three experiments. Uncertainty in each value is \pm 0.05 .

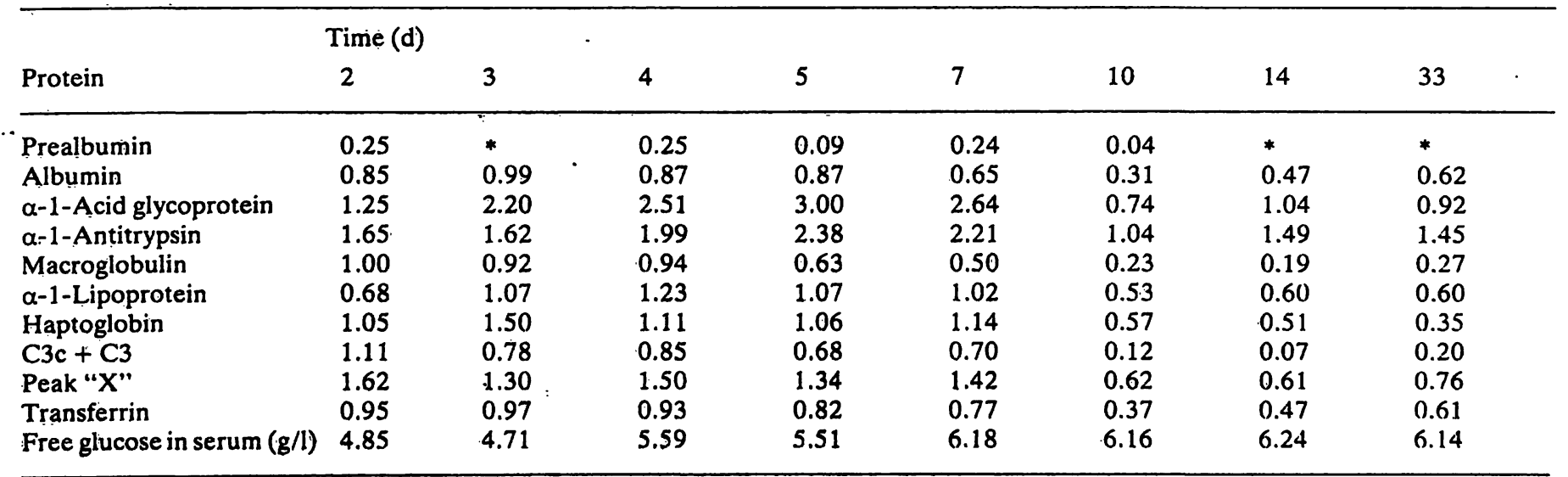

*) Peak visually not apparent. 
a slight reduction in the total free glucose $(11 \pm 5 \%)$ in the serum (tab. 2). This is not a typical acutephase reaction, which implies that the addition of the poorly controlled sugar residues onto the polypeptide chain in diabetic rat liver - a post ribosomal process - is a main pathway of glucose metabolism.

Tab. 2. Relative concentration of plasma proteins of diabetic rats injected with carageenan, in comparison to 14-days diabetic control. Values are the average of three experiments. Uncertainty in each value is \pm 0.05 .

\begin{tabular}{|c|c|c|c|}
\hline \multirow[b]{2}{*}{ Protein } & \multicolumn{3}{|c|}{ Time (d) } \\
\hline & 1 & 2 & 3 \\
\hline Prealbumin & 1.39 & 0.54 & 0.74 \\
\hline Albumin & 1.04 & 0.73 & 0.62 \\
\hline$\alpha-1$-Acid glycoprotein & 2.33 & 4.15 & 3.98 \\
\hline$\alpha-1$-Antitrypsin & 1.41 & 1.18 & 0.97 \\
\hline Macroglobulin & 0.96 & 0.65 & 0.66 \\
\hline$\alpha$-1-Lipoprotein & 1.40 & 1.29 & 1.29 \\
\hline Haptoglobin & 3.75 & 5.60 & 1.80 \\
\hline $\mathrm{C} 3 c+\mathrm{C} 3$ & 3.10 & 1.22 & 1.12 \\
\hline Peak "X" & 2.33 & 2.62 & 1.73 \\
\hline $\begin{array}{l}\text { Relative concentration of free glucose } \\
\text { in serum }\end{array}$ & 0.88 & 0.95 & 0.84 \\
\hline
\end{tabular}

Our deductions are supported by the observations of Jonsson \& Wales on levels of glycoproteins in the blood of patients with diabetes mellitus (15). In conclusion, the results of the present study suggest that in diabetic rat livers:

a) there is increased activity of rough endoplasmatic reticulum bound polyribosomes in translating mRNAs,

b) activities of glycosyl transferases are almost normal (for an opposite point of view see data of Sarnecka et al. (16)) and

c) increased glycoprotein synthesis is indicative of additional pathological complication and is not due to diabetes injury alone.

\section{Thioacetamide-induced liver cirrhosis}

Over a period of 140 days, rats developed liver cirrhosis when their drinking water was supplemented with thioacetamide $(300 \mathrm{mg} / \mathrm{l})$. The results showed that:

a) although, at the end of the experiment, histological examinations revealed severe liver damage with single hepatocytes in a matrix of collagen, acute-phase reaction was not evident and

b) the initial depression of the levels of the plasma proteins, except for $\alpha$-1-antitrypsin, haptoglobin and $\beta$-lipoprotein, was followed by a steady state or a mild build up of plasma proteins (fig. 2).

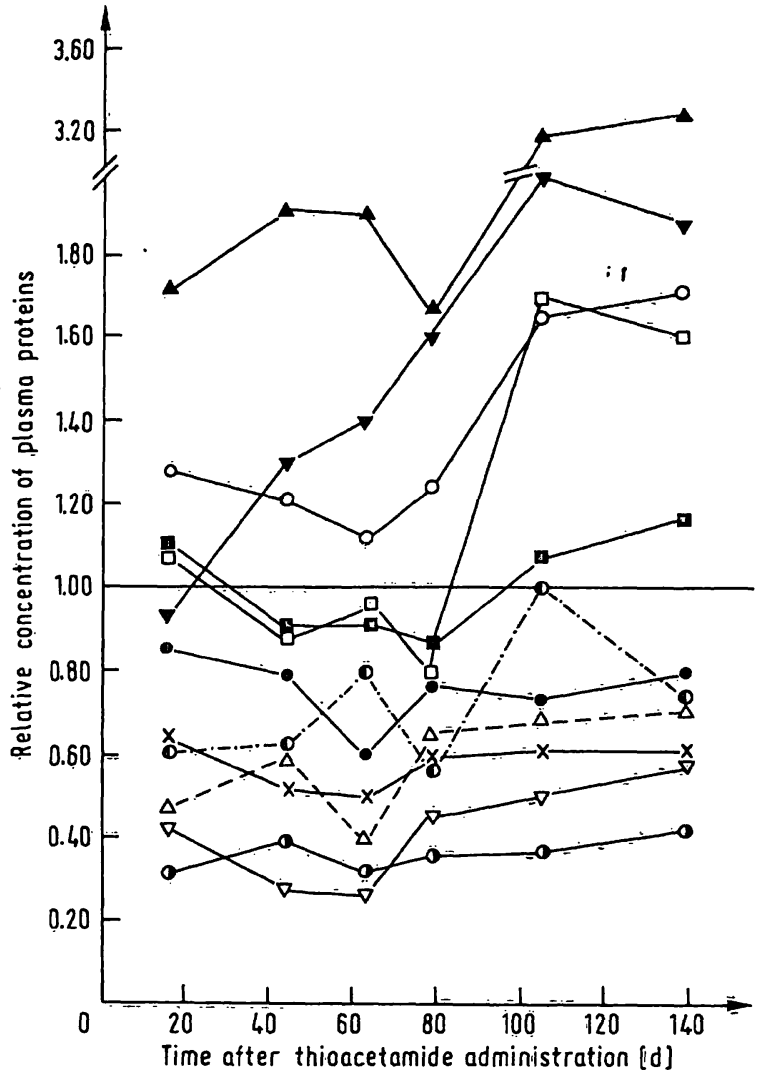

Fig. 2. Relative concentration of plasma proteins of thioacetam= ide intoxicated rats, mean standard deviation in brackets.

$$
\begin{aligned}
& -\mathbf{O}-\text { albumin }(0.02) \\
& -X-\alpha-1 \text {-acid glycoprotein }(0.22) \\
& -O-\alpha \text {-1-antitrypsin }(0.02) \\
& -\square-\text { peak "X" }(0.07) \\
& -O-\text { macroglobulin }(0.02) \\
& -\Delta-\alpha \text {-lipoprotein }(0.03) \\
& -\Delta-\text { haptoglobulin }(0.14) \\
& -\square-\text { transferrin }(0.03) \\
& -O-\text { C3c }+C 3(0.04) \\
& -\Delta-\text { prealbumin }(0.06) \\
& -\Delta-\beta \text {-lipoprotein }(0.04)
\end{aligned}
$$

This may be explained on the basis that:

a) early intoxication with thioacetamide resulted in reduction of the number of rough endoplasmatic reticulum-bound polyribosomes per volume of cytoplasm, and

b) at later stages of liver cirrhosis, the decreasing number of viable hepatocytes in liver is counteracted by the increased translation of mRNA by rough endoplasmatic reticulum-bound ribosomes.

This effect seems to be selective however, e.g., $\dot{\alpha}-\mathrm{li}-$ poprotein levels ranged between -30 to $-60 \%$, compared with healthy rats, whereas $\beta$-lipoproteins increased steadily to $+99 \%$ (a useful marker!)

\section{Regenerative activity of cirrhotic livers}

Rats with severe liver cirrhosis (139 days) were given fresh water three days prior to and two weeks af- 
ter partial hepatectomy. Histology disclosed that liver cells of the control and partially hepatectomized rats appeared to be normal and most of the collagen separating the liver cells had disappeared. However, no regenerative activity was detected as measured by $\left[{ }^{3} \mathrm{H}\right]$ thymidine incorporation. Furthermore, the mass and the volume of the remaining liver lobes in the partially hepatectomized animals remained the same for a period up to two weeks.

The effect of blocking DNA synthesis on plasma protein profile: Ixoten Model

Ixoten, a cytostatic reagent, was successful in healing rats bearing Yoshida sarcoma. The tumour was allowed to reach $15-22 \%$ of the total weight of the rat, followed by i.p. injection of ixoten $(100 \mathrm{mg} / \mathrm{kg}$ body weight). In a different set of experiments the tumour was removed surgically prior to the i.p. injection of ixoten $(100 \mathrm{mg} / \mathrm{kg}$ body weight). As expected, healing was associated with increased levels of albumin, $\alpha-1$-macroglobulin and transferrin with concomitant depression in the levels of $\alpha-1$-acid glycoprotein, haptoglobin, haemopexin and peak " $\mathrm{X}$ " (tab. 3) which is a typical response to a recovery from an inflammatory or cancerous process (2).

In control rats, injected i.p. with $50 \mathrm{mg}$ ixoten per $\mathrm{kg}$ body weight, a mild response was observed on the 2nd day and the acute-phase reaction was delayed to the 7th and 14th day (tab. 4) which is in contrast to chemical injury by carageenan (3). This delayed effect may be due to the inability of rough endoplasmatic reticulum bound polyribosomes of rat liver to actively translate mRNAs of $\alpha$-1-acíd glycoprotein and haptoglobin under the effect of ixoten.
Thus, the late acute-phase reaction may be triggered by one of the ixoten metabolites. Our thesis complies with the observation that by comparison, rats injected with a higher dose of ixoten $(100 \mathrm{mg} / \mathrm{kg}$ body weight) showed a different pattern of acute-phase reaction of the 6 th day (tab.4). This response was sharply depressed during the 2 nd and 4 th week of the experiment by the additional injection of ixoten (100 mg/kg body weight) (tab. 4). Therefore, a depressed acute-phase reaction may not necessarily imply healing from Yoshida sarcoma, but may be due to interaction of ixoten with the liver cells, unless the phenomenon is associated with elevation in albumin levels in serum.

In conclusion, even though the three agents used in the present study or their metabolites directly interacted with liver cells, they did not evoke an uniform plasma protein profile. Therefore clinical deductions based on acute-phase proteins in serum should be treated with circumspection.

Tab. 3. Relative concentration of plasma proteins of rats a) bearing Yoshida sarcoma $15-22 \%$ of total weight of rat,

b) 30 days after injecting rats bearing Yoshida sarcoma with ixoten $(100 \mathrm{mg} / \mathrm{kg}$ body weight),

c) 30 days after surgical removal of the tumour and injection with ixoten $(100 \mathrm{mg} / \mathrm{kg}$ body weight).

\begin{tabular}{llll}
\hline Protein & $\mathrm{a}$ & $\mathrm{b}$ & $\mathrm{c}$ \\
\hline Albumin & 0.48 & 0.86 & 0.98 \\
$\alpha$-1-Acid-glycoprotein & 6.83 & 1.66 & 0.66 \\
$\alpha$-1-Macroglobulin & 0.17 & 0.96 & 0.96 \\
Haptoglobin & 4.08 & 2.15 & 1.81 \\
Haemopexin & 1.95 & 1.23 & 1.52 \\
Peak "X" & 2.78 & 1.42 & 0.92 \\
Transferrin & 0.94 & 0.96 & 1.06 \\
\hline
\end{tabular}

Tab. 4. Relative concentration of plasma proteins of rats injected with ixoten.

\begin{tabular}{|c|c|c|c|c|c|c|c|}
\hline \multirow[b]{2}{*}{ Protein } & \multicolumn{2}{|c|}{$\begin{array}{l}\text { Ixoten } \\
\text { ( } 50 \mathrm{mg} / \mathrm{kg} \text { body weight) } \\
\text { Time (d) }\end{array}$} & \multirow[b]{2}{*}{14} & \multicolumn{3}{|c|}{ (100 mg/kg body weight) } & \multirow[b]{2}{*}{28} \\
\hline & 2 & 7 & & 6 & 9 & 16 & \\
\hline Albumin & 0.87 & 1.00 & 1.14 & 0.75 & 0.84 & 0.61 & 1.06 \\
\hline$\alpha-1$-Acid glycoprotein & 1.07 & 0.86 & 2.55 & 5.18 & 1.54 & 1.45 & 0.67 \\
\hline a-1-Macroglobulin & 0.85 & 1.19 & 1.00 & 0.60 & 0.85 & 0.68 & 1.07 \\
\hline Haptoglobin & 1.70 & 2.56 & 1.29 & 1.67 & 0.70 & 1.30 & 0.61 \\
\hline Haemopexin & 1.02 & 1.70 & 1.21 & $*$ & $*$ & $*$ & * \\
\hline Peak "X" & 1.07 & 1.37 & 1.71 & 2.28 & 1.27 & 1.17 & 1.11 \\
\hline Transferrin & 0.80 & 1.10 & 1.43 & 0.86 & 0.84 & 0.79 & $0.9 \mathrm{~S}$ \\
\hline
\end{tabular}

*) Peak was visually not apparent. Values are the average of three experiments. Uncertainty in each value is \pm 0.05 . 


\section{References}

1. Koj, A. (1974) Acute-Phase Reactants, Structure and Function of Plasma Proteins (A. C. Allison, ed.) pp. 73-131, Plenum Press, London.

2. Abd-El-Fattah, M., Scherer, R., Fouad, F. M. \& Ruhenstroth-Bauer, G. (1981) Cancer Res. 4I, 2548-2555.

3. Scherer, R., Abd-El-Fattah, M. \& Ruhenstroth-Bauer, G. (1977) Perspectives in Inflammation pp. 437-444, MTP Press, Lancester.

4. Fouad, F. M., Scherer, R., Abd-El-Fattah, M. \& Ruhenstroth-Bauer, G. (1980) Eur. J. Cell Biol. 21, 175-179.

5.. Uriel, J. (1964) Immunoelectrophoretic analysis (P. Garbon \& P. Burtin, eds.), p. 30, Elsevier, Amsterdam.

6. Abd-El-Fattah, M., Scherer, R. \& Ruhenstroth-Bauer, G. (1976) J. Mol. Med. 1, 211-221.

7. Barthelmai, W. \& Czok, R. (1962) Klin. Wochenschr. 40, 585-589.

8. Higgins, G. M. \& Anderson, R. M. (1931) Arch. Pathol. 12, 186-202.
9. Peterson, D. T., Alford, F. P., Deyama, I., Reaven, E. P. \& Reaven, G. M. (1973) J. Clịn. Invest. 52, 3201-3211.

10. Alford, F. P., Millea, M. E., Reaven, E. P., Shorenstein, $\dot{R}$. G. \& Reaven, G. M. (1975) Diabetologia 11, 191-200.

11. Reaven, E. P., Peterson, D. T. \& Reaven, G. M. (197.3) J. Clin. Invest. 52, 284-262.

12. Korner, A. (1960) J. Endocrinol. 20, 256-265.

13. Gưżdek, A., Sarneka-Keller, M., Dubin, A. (1979) Horm. Metab. Res. 11, 107-111.

14. Sternlieb, I. (1977) Membrane Alterations as a Basis of Liver Injury (H. Popper, L. Bianchi \& W. Reutter, eds.) pp. 88-95 and references therein, Spottiswoode Ballantyne Press, London.

15. Jonsson, A. \& Wales, K. J. (1976) Diabetologia 12, $245=$ 250.

16. Sarnecka-Keller, M. \& Kordowiak, A. (1977) Acta Biochim. Pol. 24, 179-185.

Prof. Dr. G. Ruhenstroth-Bauer Max-Planck-Institut für Biochemie $\mathrm{D}-8033$ Martinsried bei München 


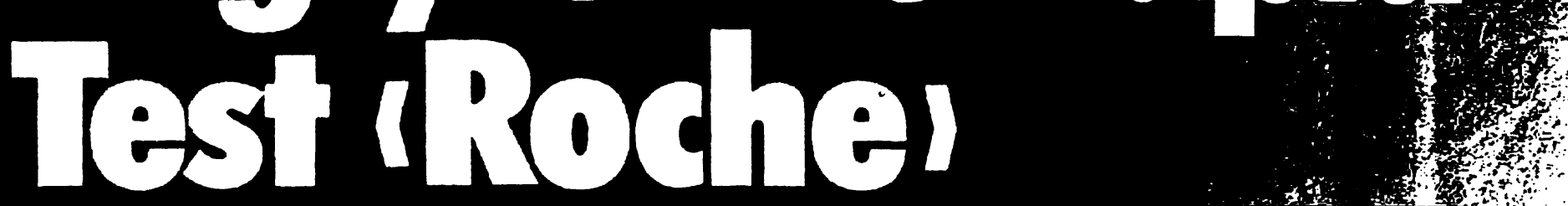

\section{vollenzymatischer Test mit Trockengranulat $\mathrm{zi}$ ecigajs}

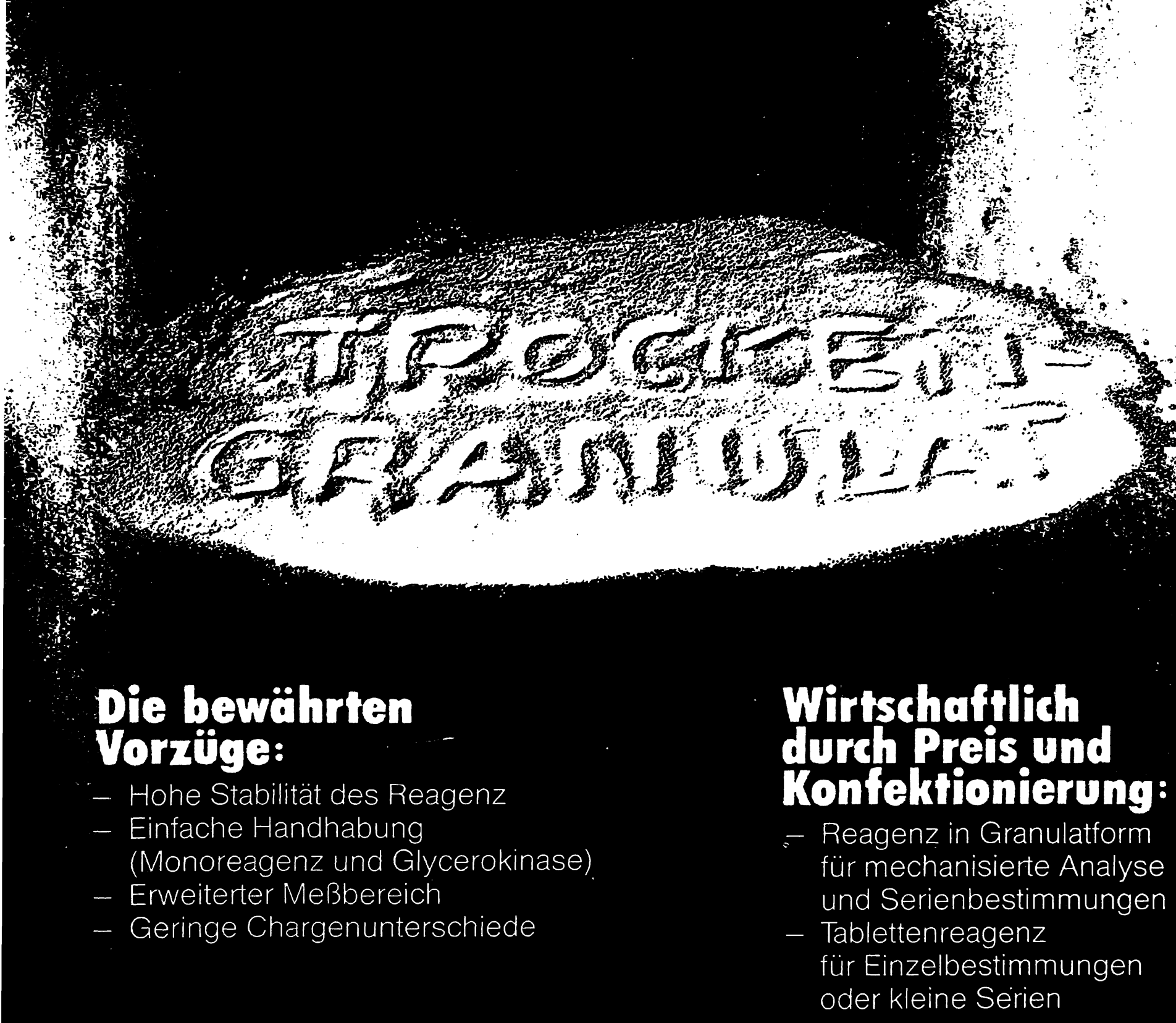

Testpackungen: Artikel Nr. 1070 (Granulatreagenz $14 \times 50 \mathrm{ml}$ ) Artikel Nr. 1086 (Granulatreagenz $14 \times 20 \mathrm{ml}$ ) Artikel Nr. 1066 (Tablettenreagenz $24 \times 6 \mathrm{ml}$ ) 


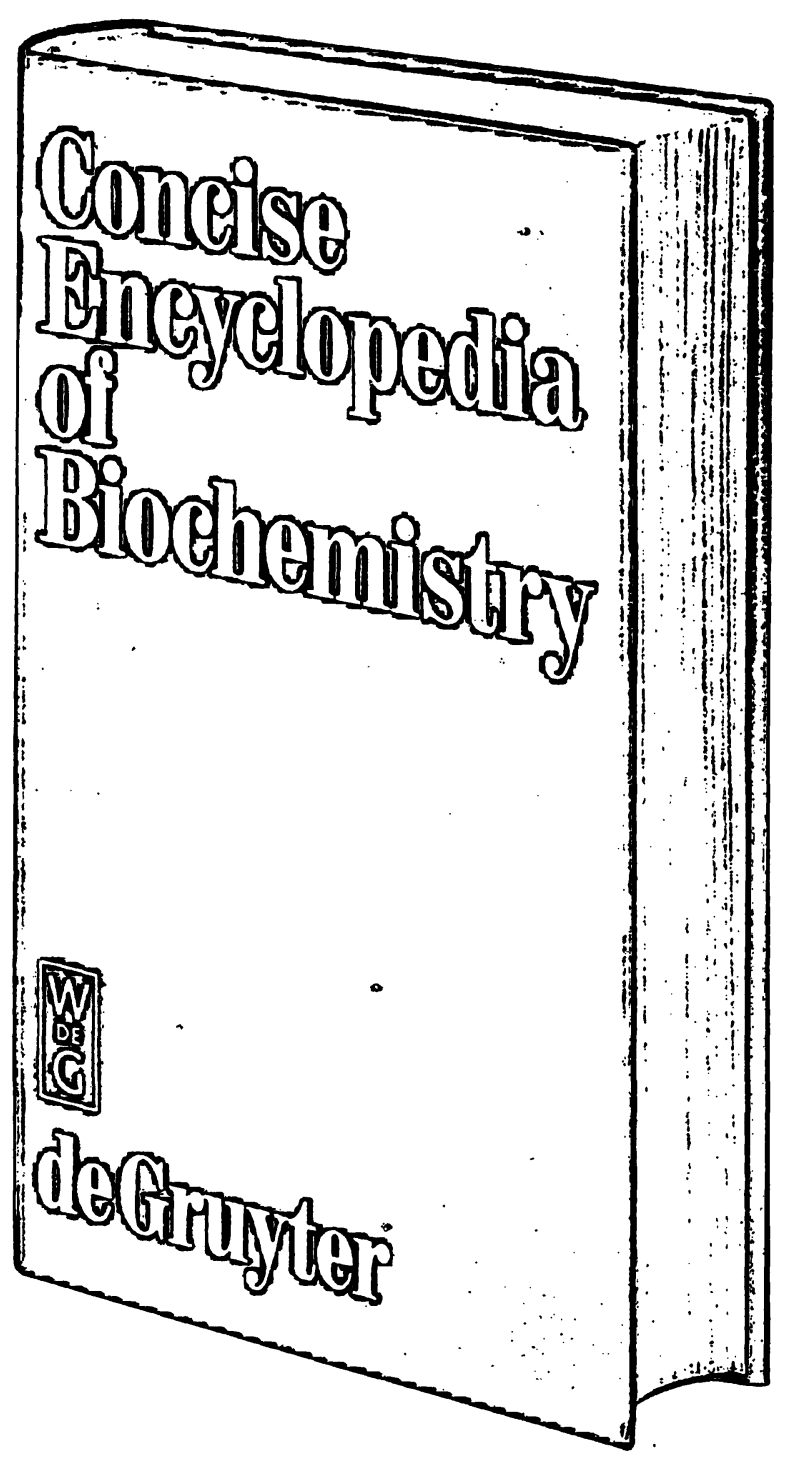

Edited by

$1983.14,0 \mathrm{~cm} \times 21,5 \mathrm{~cm}$. $\mathrm{V}, 519$ pages.

Approx. 650 illustrations. Hardcover. DM 59,-; US \$29:90 ISBN 3110078600

Prices are subject to change without notice

The Concise Encyclopedia of Biochemistry, with more than 4,200 entries, is the foremost collection of current information in this rapidly expanding field. The contents are complemented by numerous structural formulas, metabolic pathways, figures and tables. All those interested in or working in the field of Biochemistry and Biology (Life Sciences), will profit from the information contained in this encyclopedia.

This truly remarkable book is an essential reference for Biochemists, Clinical Chemists, Clinical Biochemists, Clinicians, Medical Researchers and Experimental Biologists. It will also serve as a very useful source of information for students. 